\title{
R E S E A R C H T R I A N G L E I N S T I T U T E
}

\section{DEVELOPMENT OF HIGH EFFICIENCY, LOW COST ZnSIAs ${ }_{2}$ SOLAR CELLS}

RTI Project 41U-1803

Quarterly Technical Progress Report No. 1

for

U.S. Department of Energy

MASTFD

Contract No. DE-AC04-79ET23001

April 9, 1979 to June 30, 1979

This report was prepared as an account of work sponsored by the United States Government. Neither the United States nor the United States Department of Energy, nor any of their employees, nor any of their contractors, subcontractors, or their cmployes, makes any warranty, express or implied, or assumes any legal liability or responsibility for the accuracy, completeness or usefulness of any information, apparatus, product or process disclosed, or represents that its use would not infringe privately owned rights.

\author{
J. E. Andrews, Principal Investigator \\ Research Triangle Institute \\ Post Office Box 12194 \\ Research Triangle Park, NC 27709
}




\section{DISCLAIMER}

This report was prepared as an account of work sponsored by an agency of the United States Government. Neither the United States Government nor any agency Thereof, nor any of their employees, makes any warranty, express or implied, or assumes any legal liability or responsibility for the accuracy, completeness, or usefulness of any information, apparatus, product, or process disclosed, or represents that its use would not infringe privately owned rights. Reference herein to any specific commercial product, process, or service by trade name, trademark, manufacturer, or otherwise does not necessarily constitute or imply its endorsement, recommendation, or favoring by the United States Government or any agency thereof. The views and opinions of authors expressed herein do not necessarily state or reflect those of the United States Government or any agency thereof. 


\section{DISCLAIMER}

Portions of this document may be illegible in electronic image products. Images are produced from the best available original document. 
DEVELOPMENT OF HIGH EFFICIENCY, LOW COST ZnSIAs $_{2}$ SOLAR CELLS

RTI Project 41U-1803

Quarterly Technical Progress Report No. 1

for

U.S. Department of Energy

Contract No. DE-AC04-79ET23001

Apri1 9, 1979 to June 30, 1979

J. E. Andrews, Principal Invest1gator

Research Triangle Institute

Post Office Box 12194

Research Triangle Park, NC 27709 
TABLE OF CONTENTS

1.0 INTRODUCTION .................. 1

2.0 TECHNICAL DISCUSSION ................ 2

3.0 PLANNED EFFORT . . . . . . . . . . . . . . . 4 


\subsection{INTRODUCTION}

The purpose of this study is to continue an investigation of one of the chalcopyrite semiconductors $\left(\mathrm{ZnSiAs}_{2}\right)$ in order to assess its suitability as a solar cell material. In work performed under ERDA Contract No. E(49-18)-2458, ZnSiAs, had been synthesized using an open tube vapor phase epitaxial growth technique. Epitaxial layers of $\mathrm{ZnSiAs}_{2}$ had been deposited on Ge and GaAs substrates (both (001) and (112) ZnSiAs 2 on (100) and (III) substrates, respectively).

Epitaxial deposits were routinely achieved while the surface appearance varied from mirror-like to a dull appearance which resulted from a relatively rough surface topography. Mirror-like finishes were clearly an achievable goal but required additional refinements in growth technique and substrate preparation before they could be routinely achieved.

At this time three critical goals have been identified that must be achieved before $\mathrm{ZnSiAs}_{2}$ can be realistically assessed.

1. Hole concentrations must be reduced from the current $10^{18}$ to $10^{19} / \mathrm{cm}^{3}$ range to the $10^{16}$ to $10^{17} / \mathrm{cm}^{3}$ range.

2. N-type $\mathrm{ZnSiAs}_{2}$ must be demonstrated.

3. ZnSiAs 2 p-n junctiono must be demonstrated.

The remainder of this report addresses the approach taken and the progress made toward achieving these goals as well as the planned effort for the next quarter. 


\subsection{TECHNICAL DISCUSSION}

\section{Materials Growth Activity}

The high carrier concentrations observed in the earlier p-ZnSiAs 2 were observed in growth on GaAs substrates. In particular, the Cr-doped (100) GaAs substrates that were used to facilitate Hall effect measurements resulted in autodoping of the $\mathrm{ZnSiAs}_{2}$ layers with $\mathrm{Ga}$. For this reason, the growth during this research was limited to Ge substrates, which provide the next best lattice match to $\mathrm{ZnSiAs}_{2}$. The Ge substrates used were n-type (undoped) with a resistivity of 10 to $40 \Omega-\mathrm{cm}$.

$\mathrm{ZnSiAs}_{2}$ was deposited using the original VPE system throughout the 650 to $670^{\circ} \mathrm{C}$ temperature range in order to determine the effect of temperature on morphology. While epitaxial deposits were achieved, the desired mirror-like finish was not consistently achieved.for any one temperature throughout this range for the $\mathrm{p}^{\mathrm{ZnSiAs}}{ }_{2}$. It was noted, however, that more regular growth features were obtained in the 660 to $670^{\circ} \mathrm{C}$ range.

\section{$\underline{\mathrm{n}-\mathrm{ZnSiAs}} 2$}

Deposits were obtained at the $670^{\circ} \mathrm{C}$ setting on two $100 \mathrm{Ge}$ substrates. The second substrate (located approximately 1 inch downstream on the firat substrate) had a mirror-like finish that was n-type and exhibited a $5.525 \AA$ A cubic lattice constant that is within 0.4 percent of the cubic ZnSiAs $_{2}$ lattice constant $(5.542$ A reported by Stroud, Clark, and springthorpe'). This essentially reproduces the results that had been nhtained carlier using this growth system under these growth conditions.

\footnotetext{
*Stroud, Clark, and Springthorpe, J. Cryst. Growth, 26 (1974), pp. 183185.
} 


\section{Electrical Evaluations}

$\mathrm{ZnSiAs}_{2}$, deposited on quartz substrates for the purpose of electrical measurements, exhibited very high resistivity which was believed to be due to a large number of microcracks that resulted in completely isolated islands of $\mathrm{ZnSiAs}_{2}$. Secondly, In contacts that were successfully used on the epitaxial $\mathrm{ZnSiAs}_{2}$ would not wet the layers deposited on quartz: Depositions on quartz. substrates for the purpose of electrical evaluations were discontinued.

\section{Ion Implantation.}

Seven $\mathrm{ZnSiAs}_{2}$ layers were implanted with $4 \mathrm{keV}$ Se ions at a dose of $5 \times 10^{13}$ ions $/ \mathrm{cm}^{2}$ and were subsequently coated with $\mathrm{SiO}_{2}$. The samples will be annealed and evaluated during the early part of the next report period. This work was performed courtesy of Dr. James Comas, Naval Research Laboratories, Washington, D.C.

\section{Organometallic Growth Approach}

The original open tube vapor phase epitaxial growth system used to synthesize $\mathrm{ZnSiAs}_{2}$ layers under the original contract and during the majority of this quarter has been converted to an RF induction heated organometallic syṣtem. This system will use an RF heated graphita suoceptor to provide the required substrate temperature plus employ $\mathrm{Zn}\left(\mathrm{CH}_{3}\right)_{2}$ (dimethyl zinc or $\mathrm{DMZn}$ ) in lieu of elemental $\mathrm{Zn}$ plus the previously used $\mathrm{SiH}_{4}$ and $\mathrm{AsH}_{3}$. The advantage of this system is that premature $\mathrm{SiH}_{4}$ decompooition will be prevented, and extraneous wall deposits will be eliminated. The reactor has been fabricated and is a quartz tube with a single inlet reactant entry plus uses a water jacketed design to permit water cooling the reactor walls. This system is expected to improve $\mathrm{zn}$ transport rate control as well as improve turn-around time by virtue of 
the greatly reduced thermal mass and a back-flushed o-ring substrate loading port. Conversion to this system has been completed except for the loading port, whose delivery from the machine shop was delayed by one week.

\subsection{PLANNED EFFORT}

Planned effort for the next quarter includes determining growth conditions for the organometallic system and evaluating the deposited layers.

The ion implanted samples will be annealed and characterized to determine if the material was type converted and to look for $p-n$ junction behavior. Additional samples will be submitted for continued ion implantation studies.

Emphasis during the upcoming period will be placed on measuring and reducing the carrier concentration of the $\mathrm{p}-\mathrm{ZnSiAs}_{2}$ layers using the new growth system. Synthesis and evaluation of the n-ZnSiAs; will be continued.

No problems are anticipated at this time that will impede this effort. 